\title{
FENNTARTHATÓ FENNTARTHATÓSÁG
}

\section{SUSTAINABLE SUSTAINABILITY}

\author{
Hanula Barna ${ }^{1}$, Németh Péter ${ }^{2}$ \\ 1egyetemi docens, Széchenyi István Egyetem Audi Hungaria Járműmérnöki Kar, Belsőégésű Motorok és Járműhajtások Tanszék, Győr, \\ hanula@sze.hu \\ ${ }^{2}$ MSc-hallgató, Széchenyi István Egyetem Audi Hungaria Jármümérnöki Kar Jármümérnöki angol MSc-képzés, Győr; \\ ügyvivő-szakértő, Széchenyi István Egyetem Audi Hungaria Jármümérnöki Kar Dékáni Titkárság, \\ nemeth.peter@sze.hu
}

\section{ÖSSZEFOGLALÁS}

Az energiatermelés globális adatai sajnos azt mutatják, hogy az emberiség egyik legsikertelenebb projektje a megújuló energiatermelés. A primer fosszilis energiahordozók aránya a világ energiatermelésében 1990-ig folyamatosan csökkent. Azóta nem sikerült ebben további jelentős csökkenést elérni, annak ellenére, hogy óriási befektetésekkel és költségekkel számottevő megújuló energiaforrás épült ki. Célunk a helyzet elemzése, annak teljes komplexitásában. A megállapításaink azt mutatják, hogy óriási energetikai beruházásokat valósítottunk meg azok teljes életciklus elemzése (LCA) nélkül. De a teljes kép még ennél is kedvezőtlenebb. Az LCA módszertanán túl olyan műszaki, szociális és természeti kölcsönhatások sejlenek fel, amelyek a megújulók pozitív hatásait teljesen meg is semmisíthetik.

\section{ABSTRACT}

The global figures of energy production are showing that mankind has not performed too many projects in history with such little success like renewable energy production. The percentage of fossil primary energy in the world energy production was sinking until 1990 . Since that, no more significant reduction is achieved, despite the huge financial expenditure in renewables. We analysed the situation in its full complexity. Our finding is that crucial decisions were made without analysing the whole life-cycle (LCA) of the energy systems. But the whole picture is even worse. Beyond the methodology of LCA there might be fatal interactions of technical, social and natural systems which can completely eliminate the positive effect of renewables.

Kulcsszavak: klímavédelem, $\mathrm{CO}_{2}$-csökkentés, megújuló energiaforrások, energiaátmenet, karbonlábnyom

Keywords: climate protection, $\mathrm{CO}_{2}$ abatement, renewables, energy transition, carbon footprint 


\section{ELŐSZÓ}

Az összeállítás előző cikkeiben (Szilágyi-Bereczky, 2021; Koppány-Hanula, 2021; Koppány, 2021; Szauter et al., 2021; Miskolczi et al., 2021; Hanula-Németh, 2021) bemutatott adatok és összefüggések alapján, egyszerű példákat használva igyekeztünk felhívni a figyelmet arra, hogy a környezet- és klímavédelem eszközei, illetve alkalmazásuk következményei sokkal komplexebbek, mint azt a nem tudományos médiumok, illetve az ún. általános müveltségünk alapján gondolnánk.

Ebben a cikkben megpróbálunk számot adni arról, hogy az eddigi erőfeszítések mennyire eredményesek, vagyis inkább eredménytelenek, elemezzük ennek legfőbb okait, és megpróbálunk ebből néhány fontos alapelvet levezetni, amelyek figyelmen kívül hagyása minden erőfeszítésünk eredményességét kockára teszi, viszont csak ezek betartásával lehet esélyünk jelentős eredményeket elérni a klímavédelemben.

Az egyik fontos elem az ökohatékonyság következetes szem előtt tartása, amit a második cikk tárgyal (Koppány-Hanula, 2021). Ennek az egyik gyakorlati alkalmazását mutatja jelen írás „Tisztább levegőt megfizethető módon” fejezete.

Nézzük meg, mi mindent kellene tudnunk a sikeres klímavédelemhez! Az 1. táblázat összefoglalja a szén-dioxid-emisszió meghatározásának szokásos módszertanait, és felvet két ezen túlmutató és véleményünk szerint döntő jelentőségű szempontrendszert, amelyek jelenleg sem a köztudatban, sem a tudományos értékelésekben nem látszanak érvényesülni.

1. táblázat. Az emisszió értékelésének megközelítései

\begin{tabular}{|c|c|c|c|c|c|}
\hline & 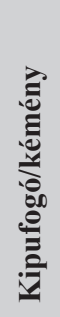 & 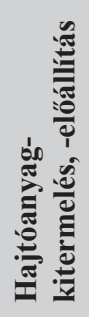 & 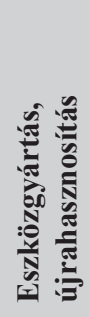 & 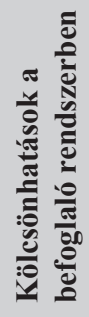 & 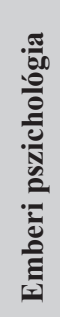 \\
\hline Tank to wheel & $\checkmark$ & & & & \\
\hline Well to wheel & $\checkmark$ & $\checkmark$ & & & \\
\hline Life Cycle & $\checkmark$ & $\checkmark$ & $\checkmark$ & & \\
\hline Life Cycle+ & $\checkmark$ & $\checkmark$ & $\checkmark$ & $\checkmark$ & \\
\hline Life Cycle++ & $\checkmark$ & $\checkmark$ & $\checkmark$ & $\checkmark$ & $\checkmark$ \\
\hline
\end{tabular}


Az első kategória az ún. tank to wheel (TTW, tüzelöanyag-tartálytól a kerekekig) megközelítés, amely csak a kipufogón/kéményen kiáramló $\mathrm{CO}_{2}$ mennyiségét veszi figyelembe. Sajnos jelenleg a legtöbb törvényi szabályozásnak ez az alapja. A legtöbb termék, így például egy személygépkocsi esetében teljesen elégtelen az üzem közben a kipufogón kibocsátott $\mathrm{CO}_{2}$ értékelése. Ennél sokkal mélyebbre kell menni, és meg kell tudni, hogy a jármü hajtásához felhasznált benzin, áram stb. mennyi $\mathrm{CO}_{2}$ árán került el a jármúig. Ez az ábra második sora a well to wheel (WTW, a kőolajkúttól a kerékig) megközelítés. Könnyü belátni, hogy különösen az ún. megújuló energiaforrások esetében mind a két megközelítés teljesen alkalmazhatatlan. Azaz feltétlenül vizsgálnunk kell a termékek gyártásának és megsemmisítésének a következményeit is. Ezt az 1. táblázat harmadik sorában láthatjuk, és jelenleg ez a legkomplexebb, nemzetközileg elfogadott módszertan. Azonban ez sem veszi figyelembe a vizsgált objektumot magába foglaló és azzal komplex kölcsönhatásba lépő ipari, gazdasági, társadalmi és természeti környezetet, melyek között jelentős és többnyire nemlineáris, sokszor pedig kaotikus kölcsönhatások lépnek fel. Ezt részletesen tárgyalja a „Megújuló energiaforrások" bekezdés.

Végezetül, sokszor döntő hatású lehet az emberi pszichológia is. Erre egy extrém példa a motorok hatásfoka. Negyven évvel ezelőtt egy Trabant gépkocsi tömege mintegy $600 \mathrm{~kg}$ volt, a teljesítménye $26 \mathrm{LE}$, a fogyasztása pedig 6-8 liter $100 \mathrm{~km}$-en. A fejlesztők sikeres munkájával a járművek hatásfokát olyan mértékben sikerült növelni, hogy egy mai SUV-gépkocsi $2000 \mathrm{~kg}$ tömeggel és $260 \mathrm{LE}$ teljesítménnyel képes ugyanilyen, 6-8 1-es fogyasztással megtenni $100 \mathrm{~km}$-t. Azaz sok ráfordítással és munkával hihetetlen eredményeket értünk el, csak éppen a környezet nem profitált belőle. Ellenkezőleg, a mai, korszerü járművek gyártása lényegesen több erőforrást igényel, és időközben Magyarországon többszörösére nőtt a járművek száma is. Sőt a Jevons-paradoxon ismeretében arra is rájöhettünk volna, hogy a kisebb fogyasztású jármủvekkel többet autózunk, hiszen a mobilitási célra fordítható összeg a jövedelmi oldalon nem csökkent. További következmény, hogy így egyre többen választják a városokban is az egyéni közlekedési eszközöket. Ettől a tömegközlekedés rentabilitása csökken, megszünnek vagy ritkábbak a járatok. Ennek következtében még többen közlekednek személygépkocsival. Sajnos a zöld rendszámos járműveknek is van ilyen járulékos hatásuk.

\section{TISZTÁBB LEVEGŐT MEGFIZETHETŐ MÓDON}

Az emisszió csökkentésének lényege mindig az volt, hogy az új eszközökre, járművekre vonatkozó határértékeket rendszeresen szigorítottuk. Nem fordítunk viszont kellő figyelmet arra, hogy az állományt milyen gyorsan cseréljük, és arra sem, hogy melyik részét. 
Az érthetőség kedveért egy konkrét példa: szeretnénk Budapest levegöjét tisztábbá tenni, mégpedig a járművek emissziójának csökkentésével. Persze ez is kérdés, hiszen tudjuk, hogy télen a szálló pornak csak 5-8\%-a származik a helyi közlekedésből, a háztartási fütőberendezések korszerüsítésével sokkal nagyobb javulást érhetnénk el. De maradjunk az autóknál. Ehhez tudnunk kell, hogy egy korszerü, Euro 6d-Temp szabványnak megfelelő személygépkocsi kipufogógázában ma már kevesebb a káros anyag, mint télen a budapesti levegőben. Azt is tudjuk, hogy az elektromos autókat egyelőre csak a tehetősebb réteg tudja megvásárolni. Mi történik tehát, ha 2,5 millió Ft támogatást adunk egy ilyen elektromos autó megvásárlására? Nagy biztonsággal feltételezhetjük, hogy a vásárlója eddig is Euro 5-ös vagy 6-os gépkocsival közlekedett, így a 2,5 millió Ft támogatással elért emissziócsökkenés alig értelmezhető. Viszont azt is tudjuk, hogy a még futó Euro 0 -s járművek között nem egy van, amelynek károsanyag-kibocsátása a maiakét akár ezerszeresen is meghaladja, illetve még rosszabb: egy láthatóan füstölö, motorjavításra szoruló jármủ a mainak egyértelmüen több ezerszeresét tudja emittálni. Ha törvényileg lehetővé tennénk és ellenőrzésekkel betartatnánk, akkor az ilyen jármüveket egy közúti ellenőrzés keretében azonnal ki kellene vonni a forgalomból, leselejtezni vagy megjavítani. Vagyis az elektromos autóra szánt 2,5 millió Ft-ból még akkor is tíz ilyen járművet tudnánk megjavítani, ha a javítás 250 ezer Ft-ba kerülne. Így a károsanyagok csökkenése több ezerszerese lenne ahhoz képest, mintha egy korszerü autót elektromosra cserélnénk. De nem csak a nyilvánvalóan meghibásodott gépjármüvekre igaz ez a gondolatmenet. Ha egy Euro 1-es jármüvet kis beruházással Euro 3-asra cserélünk, akkor az tömegében kétszer több káros anyagtól szabadítja meg a várost, mintha egy Euro 3-ast cserélnénk Euro 6-osra. A Pareto-elv itt is érvényesül, a jármüvek kb. 20\%-a felelős az emisszió mintegy 80\%-áért! Vagyis az ökohatékonyság szempontjából sokkal értelmesebb és eredményesebb lenne az emisszió szempontjából legrosszabb jármüveket kis költséggel jobbakkal helyettesíteni, mint a legkorszerübbeket még korszerübbekre cserélni. A közlekedés azonban csak egy kis része a problémának, ezért sokkal fontosabb a globális kölcsönhatásokat is vizsgálni!

\section{MEGÚJULÓ ENERGIAFORRÁSOK}

Globális összefüggések elemzésére a globális adatok a legalkalmasabbak, és ezen belül is az elektromos energia elóállításáról hozzáférhető széles körű adatok. Ezt a döntést az is indokolja, hogy az antropogén (emberi tevékenység során keletkezö) $\mathrm{CO}_{2}$ mintegy 40\%-át az áramtermelésnek „köszönhetjük”, vagyis minden más emberi energiafogyasztó tevékenységnél nagyobb a súlya. Az 1. ábrán a világbank adatai alapján mutatjuk be, hogy a világ energiafogyasztásában hány százalék a fosszilis energiahordozók aránya. 


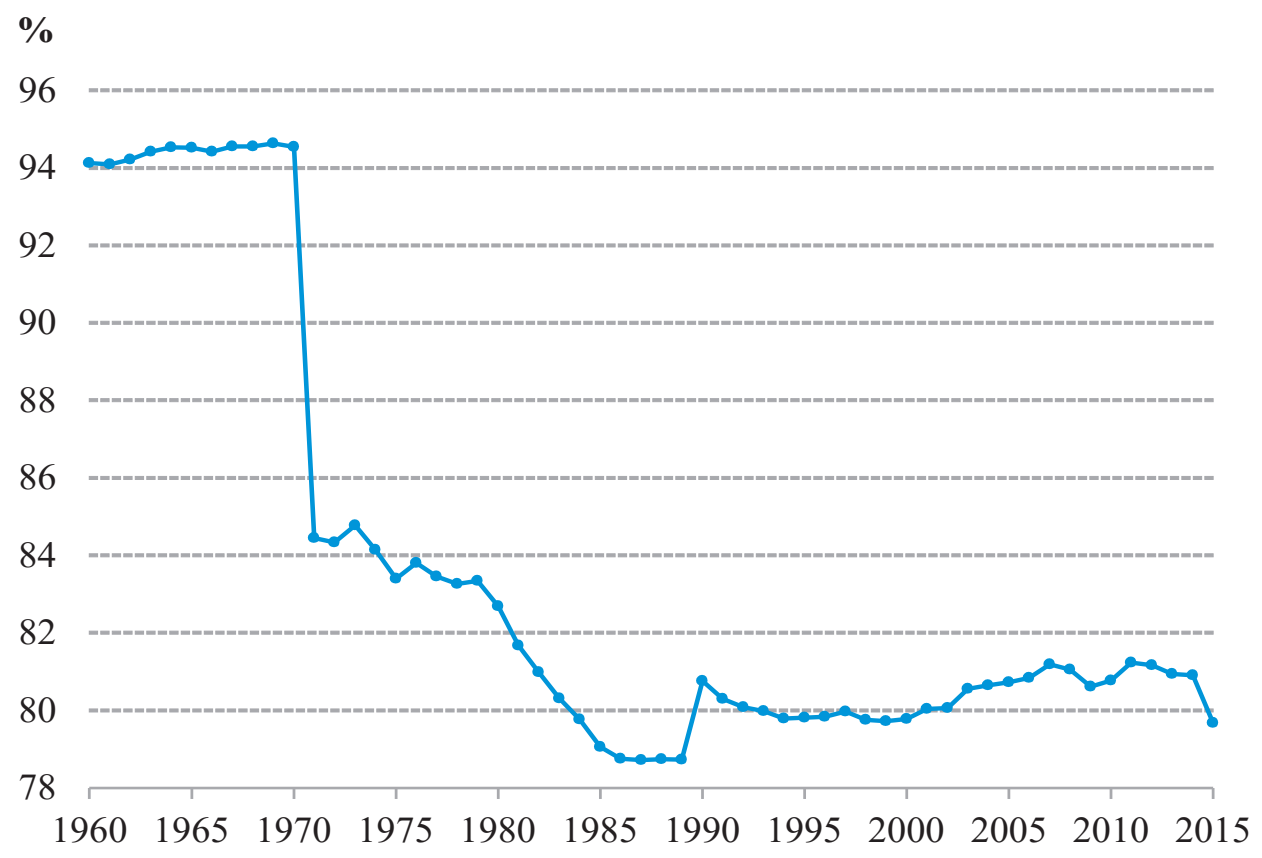

1. ábra: Fosszilis tüzelőanyagok aránya a világ energiafogyasztásában (Az adatok forrása: URL1, saját szerkesztés)

Jól látszik, hogy az 1960-as évektől 1990-ig egyértelmüen csökkenő pályán voltak a fosszilis energiahordozók, ezután azonban szinte megállt mintegy 80-81\%-os értéken. Ez azért is meglepő, mert jelentős volumenben éppen az 1990-es évektől kezdődött el a „megújuló” energiaforrások népszerüsítése és telepítése. A tudomány sajátossága, hogy szereti a paradox helyzetek kihívásait. A megfejtéshez kerestünk egy olyan országot, ahol már jelentős a megújuló energiatermelés aránya, és GDP-arányosan már több mint két évtizede jelentős erőfeszítéseket tesznek a megújuló energiák támogatására. Németország az említett kritériumoknak tökéletesen megfelel, és ráadásul sokféle részletes adatot tesz hozzáférhetővé az elemzők számára.

Az eredmények a napi híradásokban igen meggyőzőek. Németország maximális elektromos energia fogyasztása $80 \mathrm{GW}$ körüli, a telepített napelem-kapacitás $52 \mathrm{GW}^{1}$, a szélerőművi kapacitás pedig jelenleg 61,9 GW-ra tehetö. Azaz, csak ennek a két megújuló energiaformának a kapacitása meghaladja a maximális fogyasztást. Ehhez pedig még hozzá kell számítani a 4,78 GW vízi energia és a 8,21 GW biomassza kapacitást. Így nem volt meglepő 2018. január 1-jén a hír,

\footnotetext{
${ }^{1}$ Kapacitási adatok forrása: URL2.
} 
hogy a délelőtti órákban a megújulók adták az ország áramfogyasztásának több mint 90\%-át! Ezek alapján feltételezhetnénk, hogy a németországi áram kilowattórája $(\mathrm{kWh})$ lényegesen kevesebb $\mathrm{CO}_{2}$-ot tartalmaz az európai átlagnál. Az európai átlag a 2017-es számok alapján $464 \mathrm{~g} \mathrm{CO}_{2} \mathrm{e}$. A 2. ábrán jól látszik, hogy a Németországban felhasznált áram $\mathrm{CO}_{2} \mathrm{e}$ tartalma ennél magasabb, és a vizsgált kilenc év alatt nem csökkent jelentős mértékben.

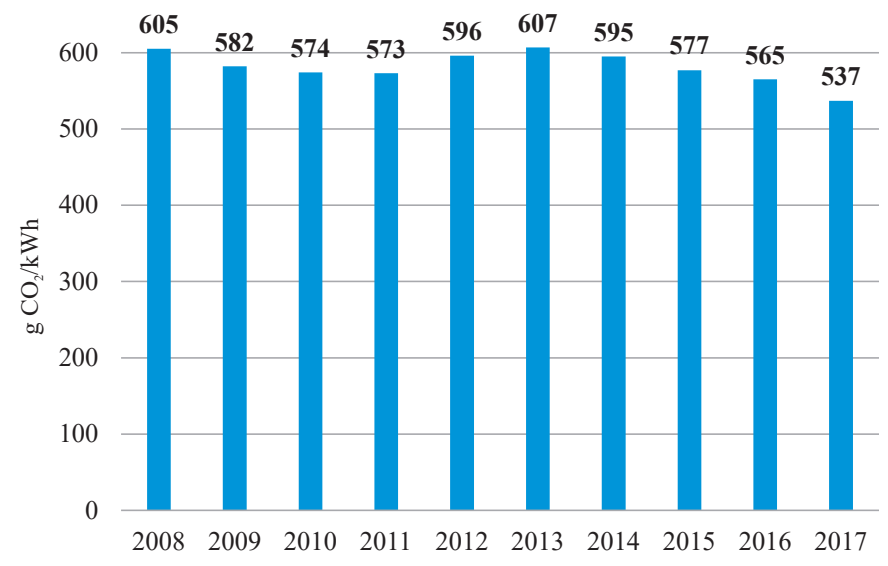

2. ábra. A Németországban felhasznált áram szén-dioxid-tartalma (Az adatok forrása: German Environment Agency - Umweltbundesamt, saját szerkesztés)

Ez a tény nyilvánvalóan tudományos elemzést érdemel és különösen azért, mert az elektromos áram $\mathrm{CO}_{2} \mathrm{e}$ tartalmára vonatkozó számok leginkább az autóknál ismert well-to-wheel megközelítésnek felelnek meg (a legtöbb forrás ráadásul csak a tank-to-wheel adatokat közli), azaz hiányzik belölük a beruházások, a kamatok vonzata vagy a beépített berendezések gyártása és reciklálása. (Például a Kínából importált napelemek gyártásával generált üvegházhatású gázok sem szerepelnek Németország mérlegében.)

A legjelentősebb ok a nap- és szélerőmüvek véletlenszerủ termelése. Az Agora Energiewende honlapon (URL3) akár napi bontásban elemezhető a németországi áramtermelés. Ezekből az adatokból könnyen kiszámolható, hogy a németországi szélerőművek átlagos kihasználtsága 18\% körüli, a napelemeké $11 \%$. Azaz a maximális, $80 \mathrm{GW}$ áramszükséglet kielégítésére szélerőmüből Németországnak $80 / 0,18=444$ GW kapacitásra lenne szüksége, napelemböl 80 / 0,11 = 727 GWra. Azonban, ha megvizsgáljuk az időbeli eloszlást, akkor találunk időszakokat, amelyekben a megújulók véletlenszerüen (2017 szeptemberében több mint két hétig, 2018 júniusában három hétig szélcsend volt a teljes országban) vagy szezonálisan (a napelemek kihasználtsága decemberben 0,5\% körüli) még így sem tudnák ellátni az országot energiával. 


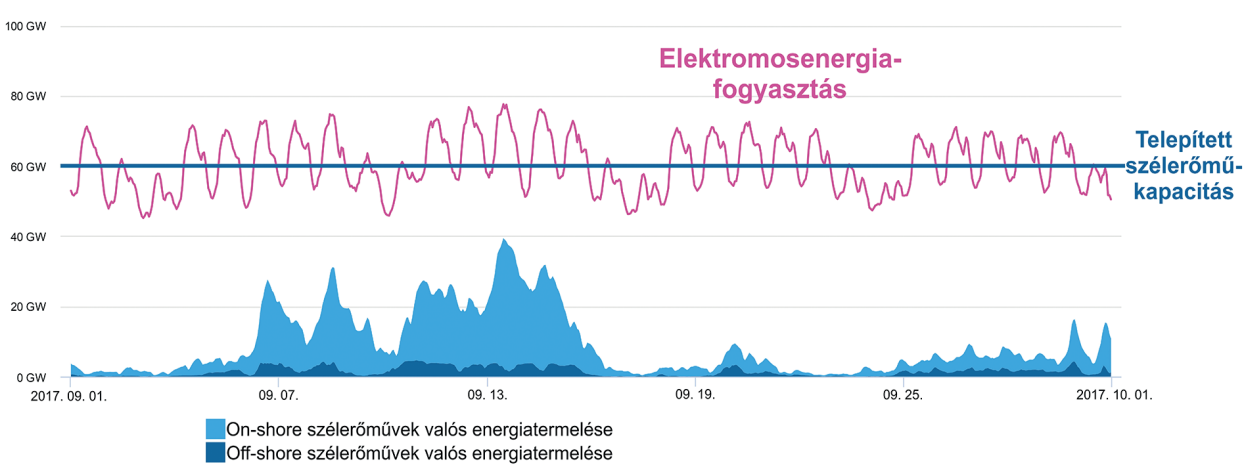

3. ábra. Németország áramtermelése 2017 szeptemberében (Agora Energiewende [2020] Agorameter alaján)

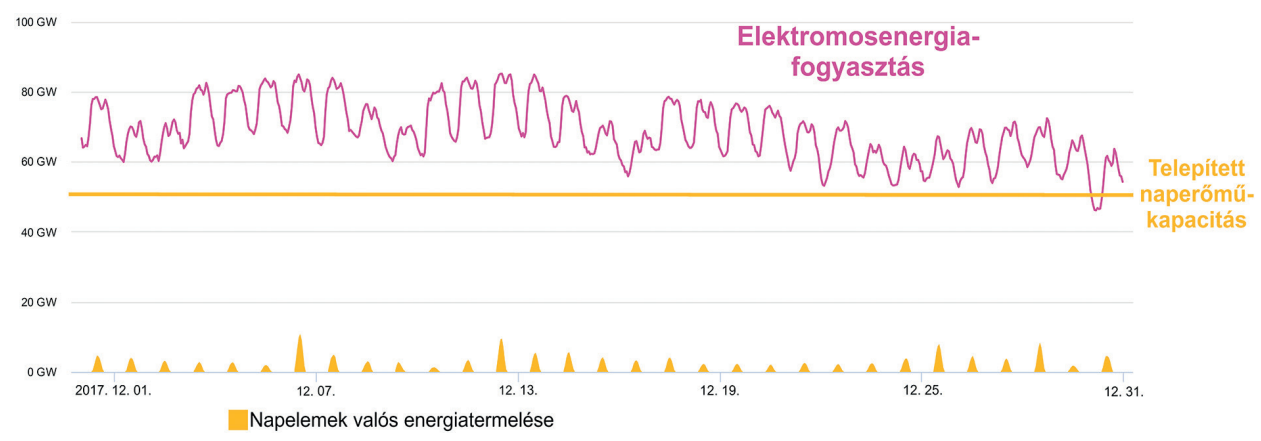

4. ábra. Németország áramtermelése 2018 januárjában (Agora Energiewende [2020] Agorameter alaján)

Azaz a technika jelenlegi állása mellett szükséges a teljes 80 GW-nyi csúcsfogyasztást lefedő nem időjárásfüggő erőmüvi kapacitás kiépítése és teljes személyzettel, esetenként felfütött állapotban történő „rendelkezésre állása”! Ami viszont visszakövethető és logikus: a fosszilis erőmüvek jelentős fejlődésen mentek keresztül az utóbbi évtizedekben. Az erőművek ezt a magas hatásfokot azonban csak a névleges terhelésükön érik el. Ha bármilyen okból ennél kisebb teljesítménnyel müködtetjük őket, akkor hatásfokuk romlik.

A német erőmüpark hatásfoka a törvényekben is előírt korszerű technológiák révén folyamatosan javul. A termikus erőmüvek átlagos névleges hatásfoka 1990 körül 37-38\% között volt, és 2011-re már elérte a 47\%-ot! A tényleges üzemi hatásfokot viszont úgy tudjuk kiszámolni, hogy a megtermelt elektromos energia mennyiségét elosztjuk az elfogyasztott tüzelőanyag fütóértékével. A különbség 1990-ben még csak néhány tized százalék volt, azóta azonban az olló fokozatosan nyílik, és a különbség 2011-re elérte az 5\%-ot! 
Egyértelmü, hogy az egyre gyakoribb leszabályozás (a megújulóknak természetesen prioritásuk van) következtében a korszerüsített berendezések potenciálját egyre kevésbé használjuk ki. Ennek leglátványosabb példája éppen az említett 2018 januárjának első két hete. Január 1-jén 12 órakor a szél- és naperőmüvek mellett mindössze $14 \mathrm{GW}$ teljesítményt kellett egyéb forrásból a hálózatba táplálni. Tíz nappal később, 11-én reggel 8 órakor viszont teljes szélcsend volt, és még a nap sem sütött, így $77 \mathrm{GW}$ teljesítmény kellett más forrásból fedezni. Ez azt jelenti, hogy 77-14 = $63 \mathrm{GW}$ teljesítményt kell az időjárás változása miatt hol „,bekapcsolni”, hol pedig kikapcsolni. Ez 31 db Paks méretü erőmü teljesítménye! Nem nehéz megérteni, hogy ezek megépítése, finanszírozása, személyzete, karbantartása, készenléti állapota és életük végén a lebontásuk közvetve és közvetlenül óriási mennyiségü $\mathrm{CO}_{2}$-emisszióval jár, amit a hivatalos adatok nem tükröznek.

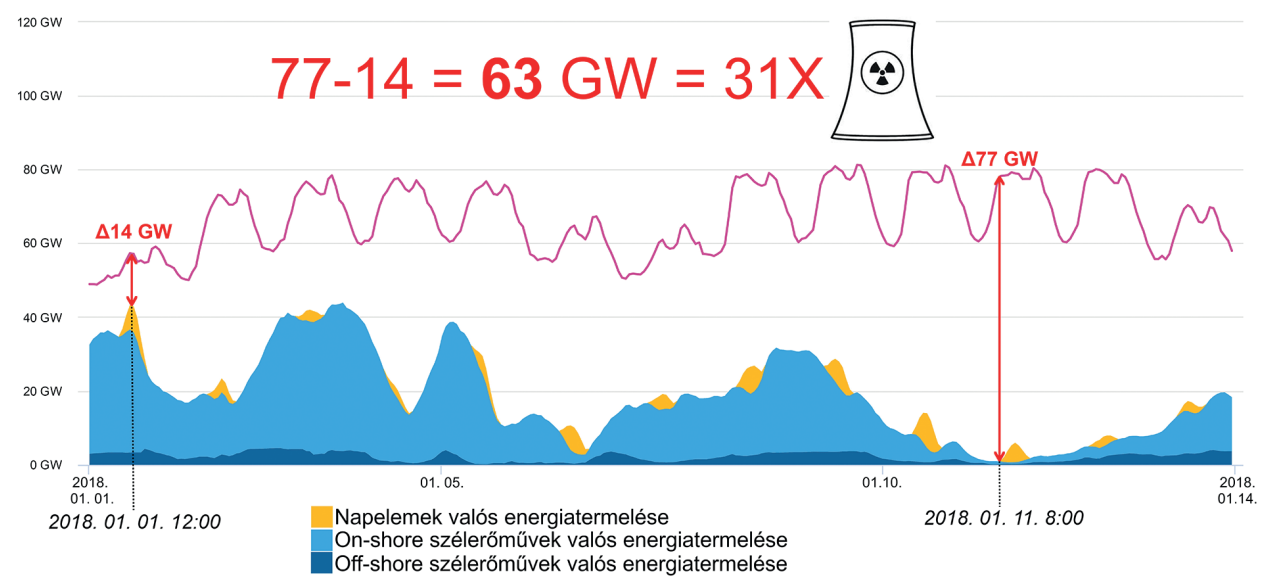

5. ábra. Megújuló energiaforrások és a német áramfogyasztás (Agora Energiewende [2020] Agorameter alaján, részben saját szerkesztés)

Azaz ebben a pillanatban be kell látnunk, hogy még a teljes életciklus-elemzés módszertana sem ad megbízható választ sorsdöntő kérdéseinkre. Az úgynevezett regeneratív áramtermelési módszerek életciklus számai már a szokásos LCA-módszertannal sem igazán jók, azaz a gyártás, szállítás, felszerelés, üzemeltetés és a karbantartás, majd a megsemmisítés $\mathrm{CO}_{2} \mathrm{e}$-emissziója sokat levon a pozitív hatásokból. A fent leírtak alapján látszik, hogy „regeneratívok” elektromos hálózatba történő integrálása olyan negatív kölcsönhatásokat generál, ami jelenlegi tudásunk szerint megkérdőjelezi a regeneratív áramtermelés ezen stratégiáját!

Természetesen felmerül az elektromos áram tárolásának a lehetősége is. Erre számtalan műszaki lehetőség létezik, például: akkumulátorok, olyan vízi erőmüvek, amelyek „fordított” üzemben vizet szivattyúznak egy magasabban fek- 
vő tározóba, amikor áramfelesleg van, és ebből termelnek áramot, amikor arra szükség van, vagy más megoldások, amelyeknél víz helyett súlyokat emelünk a magasba, vagy nagy méretű lendítőkerekeket gyorsítunk fel. Ezek azonban a legkülönbözőbb okokból jelenleg megközelítőleg sem alkalmasak például Németország elektromosenergia-igényének fedezésére.

Ezek a folyamatok máig oda vezettek, hogy Németország évente $30 \mathrm{Mrd} €$-val támogatja a megújuló energiatermelést. Ez csak az állami támogatások összege, a beruházásokba befolyó magántőke ennél magasabb összegủ.

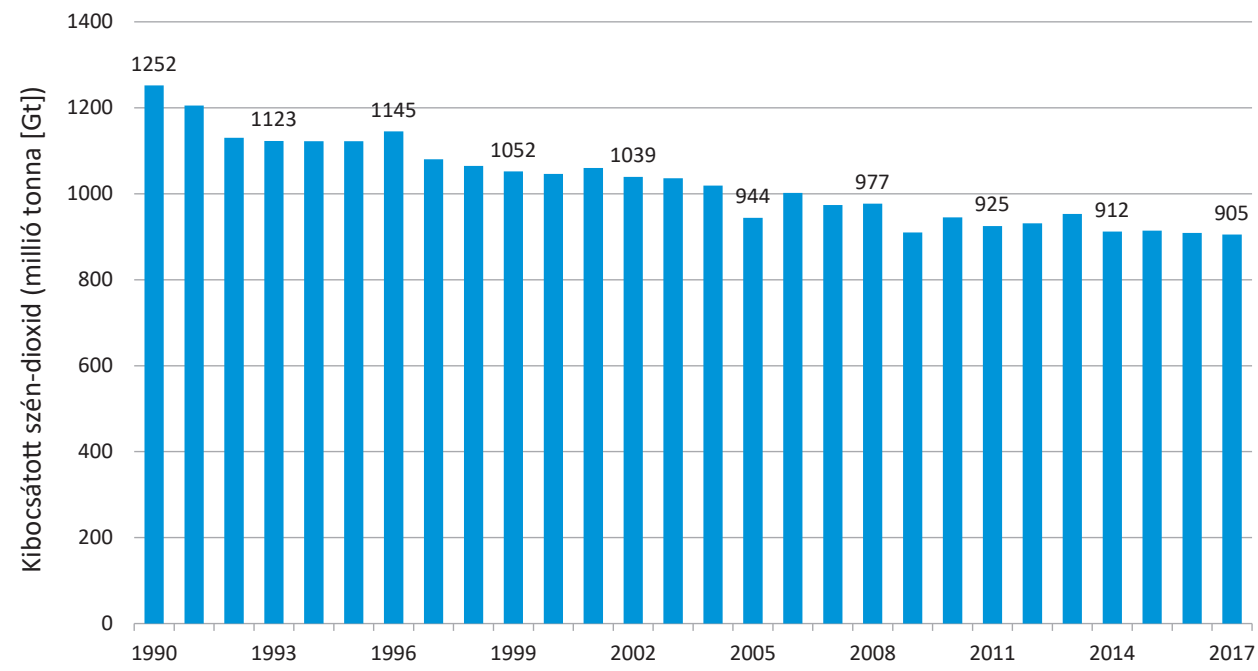

6. ábra. Németországi üvegházhatású gázok emissziója

(Az adatok forrása: Bundesministerium für Umwelt, Naturschutz und nukleare Sicherheit [BMU], saját szerkesztés)

Vizsgáljuk meg, hogy ez a hatalmas anyagi áldozat milyen eredményt generál az ország $\mathrm{CO}_{2}$-emissziójában? A 6. ábra mutatja a németországi teljes $\mathrm{CO}_{2}$-emiszsziót. Ennek értéke az elmúlt évtizedben lényegében változatlan! És a számok csak well-to-wheel szintúek, azaz az energiatermelő infrastruktúra LCA-értékelése ebben nincs benne! Ha ezt figyelembe vennénk, az már önmagában növekvő pályára állítaná a németországi áramtermelés $\mathrm{CO}_{2} \mathrm{e}$-emisszióját. $\mathrm{A}$ baj azonban még ennél is nagyobb. Koppány Krisztián és Hanula Barna kifejtették cikkükben, hogy mennyire fontos a klímavédelem szempontjából az egyes lépések ökohatékonysága és sorrendisége. Nézzünk meg néhány konkrét példát! A cikk írásakor az európai $\mathrm{CO}_{2}$-kötvény piaci ára $25 €$ körül mozgott, azaz ennyit „ért” $1 \mathrm{t} \mathrm{CO}_{2}$-emissziója, és fordítva ennyiért lehetett a gazdaságban $1 \mathrm{t} \mathrm{CO}_{2}$-emissziót elkerülni. Ha az elköltött 30 Mrd $€$-t ezzel a hatékonysággal költöttük volna el, 
akkor azzal $1200 \mathrm{Mt} \mathrm{CO}_{2}$-ot lehetett volna megtakarítani Európában, ami több mint a teljes német kibocsátás! $\mathrm{A} \mathrm{CO}_{2}$ azonban nem lokális, hanem globális probléma. Ha ugyanezt az összeget a világ összes elavult erőmüvének korszerüsítésére fordítottuk volna, és feltételezzük, hogy ezeknél $1 \mathrm{t} \mathrm{CO}$ megtakarítása „csak”

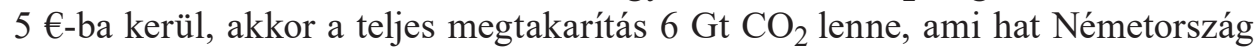
teljes emissziójának felel meg!

Vegyünk egy nagyon egyszerü példát: Tételezzük fel, hogy 500 eurót szabad akaratunkból a klímavédelem számára ajánlunk fel, de el kell döntenünk, hogy milyen technikai megoldást válasszunk.

Vegyük sorra a lehetőségeket a teljeséletciklus-számítás módszertanát alapul véve:

Egy elektromos autó esetében átlagban ez a pénz kb. 200 kg CO $2 \mathrm{e}$-megtakarítást eredményez. Sajnos $500 €$ GDP megtermelése átlagban $250 \mathrm{~kg} \mathrm{CO}_{2} \mathrm{e}$-emiszszióval jár.

- Egy hagyományos gépkocsi esetében az elérhető emissziócsökkentés durván 1 t. Ez sokkal jobbnak tünik, kérdés, hogy megéri-e?

- Egy hőerőmü kéményéből müszaki megoldásokkal ki lehet választani a $\mathrm{CO}_{2}$-ot. A költségek még inkább csak becsültek, de a források átlagából kb. 3,5 t csökkenést prognosztizálunk. Meglepő módon a szakma egyöntetű véleménye az, hogy ez még túl drága.

- Az európai iparban a $\mathrm{CO}_{2}$-kötvények jelenlegi $25 €$ körüli ára alapján azt állapíthatjuk meg, hogy a pénzünk itt $20 \mathrm{t} \mathrm{CO}_{2} \mathrm{e}$ elkerülésére lenne elegendő. Nem nehéz belátni, hogy amíg ilyen lehetőség van, addig nem lenne szabad más, drágább megoldásokba belekezdeni!

- Csak becsült érték, de újságcikkekben már találkoztunk olyan kijelentéssel, hogy egy elavult lignitet égető hőerőmü korszerüsítése esetén az $500 €$ akár 100 t $\mathrm{CO}_{2} \mathrm{e}$ elkerülésére lenne elegendő! Meggyőződésem, hogy akár elemi vállalatigazdaságtan-ismeretek birtokában is egyértelmü, hogy mindig csak az adott pillanatban leghatékonyabb lépések vezethetnek a probléma megoldásához. Az alacsony ökohatékonyságú intézkedések valójában határozottan károsak, mert elvonják a forrásokat a hatékonyaktól! És ez a magyarázat a $\mathrm{CO}_{2}$ csökkentési erőfeszítések eddigi teljes kudarcára!

Összefoglalva: a fentiekből egyértelmüen látszik, hogy ha a klíma védelmére fordított pénzt magasabb ökohatékonyságú megoldásokra fordítottuk volna, akkor már alacsonyabb lehetne mind az elektromos áram, mind pedig a pénz $\mathrm{CO}_{2}$-tartalma. Ez pedig létfontosságú ahhoz, hogy a későbbi drágább és energiaigényesebb klímavédelmi lépéseket egyáltalán meg tudjuk valósítani, illetve, hogy a leírt látens $\mathrm{CO}_{2}$-tartalom ne semmisítse meg az erőfeszítések eredményét. Más szavakkal: ha nem elég tág rendszerhatárokkal vizsgáljuk a klíma védelmére megtett lépéseinket, akkor sok esetben nagyobb kárt okoznak, mint hasznot. 
Legyen ez intő példa arra, hogy az a mondás, miszerint mindegy, hogy mit, csak az a fontos, hogy mindennap tegyünk valamit a környezetért, nem állja meg a helyét! A nem átgondolt intézkedések, a rendszerek kölcsönhatásainak figyelmen kívül hagyása, súlyos, akár fatális következményekkel járhatnak, és alapjaiban veszélyeztetik a klímaváltozás elleni harc sikerét!

Vagyis, csak a Pareto-elv figyelembevétele és a klíma védelmére bevetett technológiák helyes ,sorrendben” történő alkalmazása vezethet megoldáshoz.

\section{IRODALOM}

Koppány Krisztián (2021): A Pareto-hatékony klímavédelem és a szén-dioxid-kibocsátás csökkentési lehetőségeinek határa. Magyar Tudomány, 182, 3, 322-331.

Koppány Krisztián - Hanula Barna (2021): Mennyi szén-dioxid van egy euróban? A sikeres emiszsziócsökkentéshez globális gondolkodás, elemzés és tervezés szükséges. Magyar Tudomány, $182,3,307-321$.

Miskolczi Márk - Ásványi Katalin - Jászberényi Melinda - Kökény László (2021): Hogyan döntsön a mesterséges intelligencia? Az önvezető autók morális kérdései. Magyar Tudomány, 182, 3, 342-352.

Szauter Ferenc - Bedő Anett - Körös Péter - Friedler Ferenc (2021): Az automatizáltság növelésével a fenntarthatóságért. Magyar Tudomány, 182, 3, 332-341.

Szilágyi Artúr - Bereczky Ákos (2021): Az akkumulátoros elektromos személygépjármúvek környezeti hatásainak értékelése a teljes életciklus figyelembevételével - hol az igazság? Magyar Tudomány, 182, 3, 292-306.

URL1: https://data.worldbank.org/indicator/eg.use.comm.fo.zs

URL2: electricitymap.org

URL3: agora-energiewende.de 